\title{
OCCASIONALLY, HE'S A SOMNIATICIDAL MANIAC: STEPHEN GRAHAM JONES RECLAIMS HOME AND HISTORY
}

\author{
Theodore C. Van Alst, Jr., Portland State University, theo.vanalst@gmail.com \\ 10.31902/fll.26.2019.7 \\ UDK 791:929Džons S. G.
}

\begin{abstract}
Environmental activism and preservation of the land, acknowledgement of our shared responsibilities to the planet, to unci maka, to Mother Earth, to our home; these are obligations of love we as human beings embrace with devoted regularity. But what happens when we look at stories that might destroy the world entirely, might remold, reshape, reclaim and remake (or perhaps even "rename" in a restorative move) our histories and homes? What is the reception for works that defy the expectations of devotion to the environment in Native American literature one genre at a time? That address historic erasure by reshaping the future?

This paper will examine some of Stephen Graham Jones's prolific works, including Sterling City, "How Billy Hanson Destroyed the Earth, and Everyone on It," as well as Chapter Six, all published in a variety of platforms and collections. In each instance, the worlds as home and future history described are decidedly reclaimed, perhaps for good reasons, and perhaps for not so good reasons. The worlds offered to choose from, however, are ones that will likely give you nightmares, or at least pause, even in the daylight.
\end{abstract}

Keywords: American Indians, Stephen Graham Jones, Blackfeet, Fiction, Science-Fiction, Apocalypse und Post-Apocalypse, Zombies, Settlers, America.

Environmental activism and preservation of the land, acknowledgement of our shared responsibilities to the planet, to unci maka, to Grandmother Earth; to our home; these are obligations of love we as human beings embrace with devoted regularity. But what happens when we look at stories that might destroy the world entirely, might remold, reshape and remake (or perhaps even "rename" in a restorative move) our environment and living spaces? What is the reception for works that defy the expectations of devotion to the environment in Native American literature one genre at a time? That address historic erasure by reshaping the future?

This paper will examine some of Stephen Graham Jones's prolific human, alien, posthuman, pre- and post-apocalyptic works, including Sterling City, "How Billy Hanson Destroyed the Earth, and Everyone on It," as well as Chapter Six, all published in a variety of platforms and collections. I will assume a level of familiarity with Jones's work, but briefly, the works deal with pre- and post-apocalyptic landscapes; Sterling City with an exploded moon of Mars, "Billy Hanson" 
with a visit from the void of deep space, and Chapter Six with zombie hordes (herds?) ${ }^{1}$ in New England. ${ }^{2}$ As I put them in play with each other for this essay, I was surprised to note that all three contain representatives from academe; that is likely an added bonus for many in this audience. ${ }^{3}$ In each instance, the senses of home described are decidedly changed, perhaps for good reasons, and perhaps for not so good reasons. Ultimately, the reader elects a view, but the worlds offered to choose from are ones that will likely give you nightmares, or at least pause, even in the daylight.

Why then would Jones create these seemingly unethical (or perhaps ethics-free) landscapes? After all, in 2003's The Bird is Gone: A Manifesto, his is the Native genius that returned land to Indian people through, though what on the surface might seem as outlandish a move as possible, is likely the only way we'll ever see an additional square acre come our way; US Congressional inattentiveness/oversight. I could spend a paragraph or two of your valuable time trying to unwind Jones's singular slickness for you, but you can get right to it here:

Conservation Act-n., Hist. the accidental solution to the 'Indian Problem' (under pressure from Keep America Beautiful, the American Congress signed into law an aggressive bill requiring 'the restoration of all indigenous flora and fauna to the Great Plains.' As wildlife biologists soon pointed out, though, for a disturbance-dependent landscape to regain anything approaching self-sufficiency-to say nothing of momentumthe reintroduced grass (buchloë dactyloides) needed buffalo (bison bison) to 'disturb' it, and, just as the prairie dog (cynomys ludovicianus) needed the disturbance of the blackfooted ferret (mustela nigripes), so did the burgeoning herds of reintroduced buffalo need the INDIAN (canis latrans)) (Bird 164).

Bouteloa dactyloides is Buffalo Grass, and then again according to some, so is buchloe dactyloides, hmmm. Either works. You decide. Bison bison, cynomys ludovicianus, mustela nigripes. Those all check out. And canis latrans? Well, yeah. That's a coyote. Or an "INDIAN." Your pick.

Questions this paper hopes to answer continue. Does Jones pervert, invert, or expand the fluidity of genre to say new things about land, home, and

1 "'Do horde and herd share a root?' Crain asked." (Kindle locations 24-25).

2 For Jones's take on hordes, herds, humans, and zombies, here he is, full of sweet tea and Sixlets ${ }^{\circledR}$, laying it all down with an episode called "Zombies in Ten Minutes" over on YouTube: <https://www.youtube.com/watch?v=6alBenBs-gM>

3 Of course, though, Jones's typical characters are working class, working poor. Here he offhandedly reminds us who will bear witness, who will be the first affected in any apocalypse: "Far to the east, then, what was causing the ripple: one of the big chunks of the moon was tearing down, dragging fire. It would hit Dallas, maybe. Little Rock. Jacksonville. Some empty part of I-20, a trucker pulling his wheel away like that could possibly be enough." Sterling City, Kindle location 1209. 
worldscapes? Is Jones's use of genre transportive and transformative enough to describe old lands as new worlds-worlds better, but likely worlds worse? Or do we hope somehow that his indigeneity, his Blackfeet-ness will somehow redeem these stories as ethical? Let's have a look.

In Jones's Sterling City (It's a real place-deep in the heart of Texas, as they say. A quick look at the town wiki and other sources tells us, "The population was 1,081 at the 2000 census, but had dropped to 982 by 2009." I just checked the town website today, though, and see that it was down to 888 by 2010. Who knows what the 2020 Census may bring...), we have Mars' twin moons, Phobos and Deimos, staring down at us humans, asking how we could be so... horrible. And what of those two moons balefully gazing upon pitiful humans of earth? Why them? Let's consider what they're named and how that might affect our story.

From Classical Greek mythology, we know that Phobos is Fear (and occasionally Terror) ${ }^{4}$ and Deimos is Panic (or Horror, every now and again). And though likely easy to do, Phobos and Deimos are not to be confused in any way with the hilarious, bootlicking Disney devils Pain and Panic from their 1997 film Hercules (of course you know I would love to insert some images here, just as you of course know how impossibly expensive it would be to get the rights from Uncle Walt \& Co., so you'll have to use your imagination to envision them saying things when summoned by their boss Hades like, "Coming, your Most Lugubriousness," and "Oh. Sorry. I can handle it."). ${ }^{5}$ Rather than animated and caricatured versions of Matt Frewer and Bobcat Goldthwait, they look like these images from the village of Halicarnassus, courtesy of the British Museum:
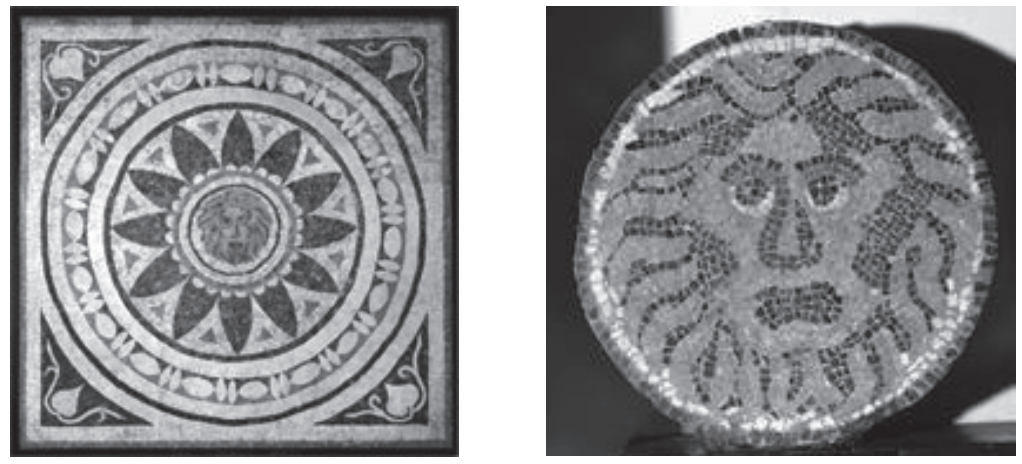

6

4 Sterling City's Doby gives us the willies with his last sentence here when he says: "It means 'fear,' that moon, or whatever. Phobos. Phobia. Stace studied it in English. If it's even a moon in the first place, I mean." Kindle locations 296-297.

5 Or you could just go here, if you'd like: <https://www.youtube.com/watch?v=1mfpiA1bymw> 6 Images of Phobos and Deimos (c) Trustees of the British Museum 
And the moons themselves? Well, they're mostly unremarkable, except for their shapes. If they were moons of Earth, well, let's just say our art, music, and iconography around La Bella Luna would be a whole lot different (and... blobbier):
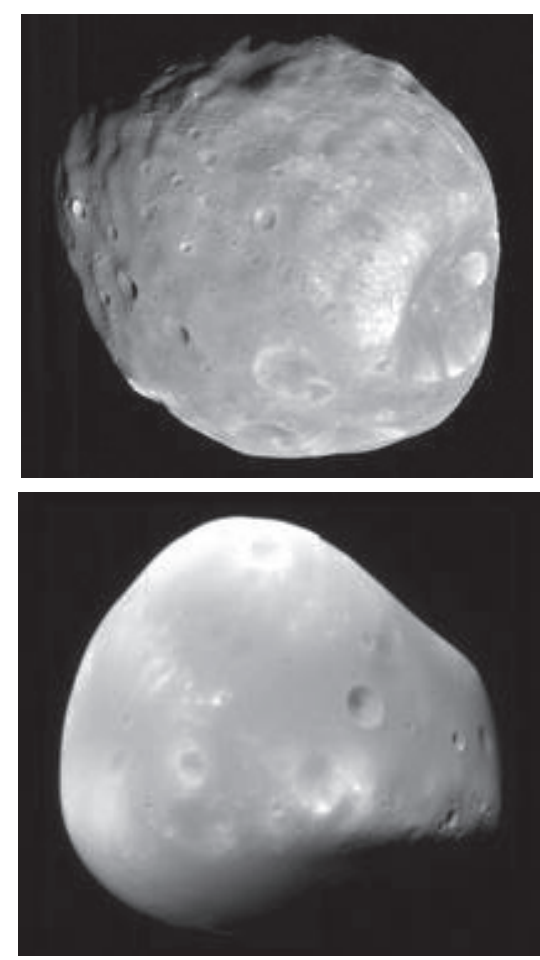

7

It is worth noting that there are only two named features on Deimos. They are both craters, deep depressions on the surface of the oddly shaped moon given - of course - writer's names. One is Voltaire (that great attacker of decrepit institutions); the other (increasing the likelihood of the asteroid's baleful stare) is named for the grim dean himself-Jonathan Swift.

Upon reflection, it's possible our twin critics do look like Phobos and Deimos-it seems a plausible enough reason for the craters being named thusly. Let's observe... No. No they don't. The portraits available describe an amiable, even affable Voltaire. For all his wicked words, he seems pretty happy for a writertype, 


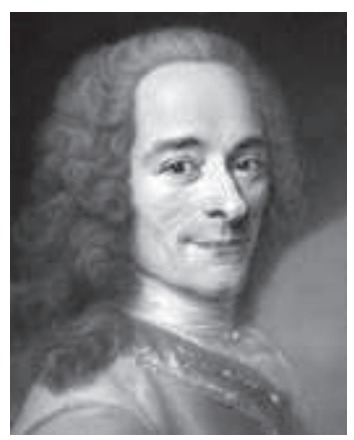

8

though pre-bewigged Swift does not disappoint:

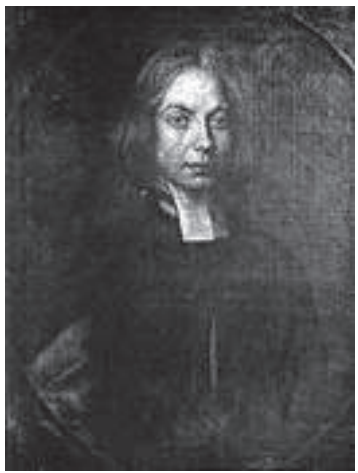

9

Perhaps the "blunt nose" of the "eight-pound probe" (Kindle Location 36) that shattered the face of Phobos found its thinnest skin in the bottom of one of those craters; in any instance, Sterling City opens with quiet apocalypse: "The night Zoe left, it rained fire." ${ }^{10}$ Jones situates that resultant flaming cosmic deluge near a description of the offending Martian probe (a probe of assumed American origin): "The pictures of it looked cartoonish to Lee, like the footage of the rounded-off A-bombs that had floated down onto Hiroshima and Nagasaki." ${ }^{\prime 1}$ The horrifically destructive power of those atomic bombs, and the devastating toll on the earth in the extraction of the materials required to make them, is well known to Native people; estimates vary, but up to half of the "U.S." supply of uranium is located on or near Indian reservations. ${ }^{12}$ The omnicidal

$8 \mathrm{http}: / /$ upload.wikimedia.org/wikipedia/commons/c/c2/D\%27après_Maurice_Quentin_de_La_ Tour\%2C_Portrait_de_Voltaire\%2C_détail_du_visage_\%28château_de_Ferney\%29.jpg

9 http://en.wikipedia.org/wiki/File:Jonathan_Swift_At_Trinity_College.jpg

10 Sterling City Location 29

11 Ibid. Locations 36-37.

12 K. Frantz, 'The Role of Mining on Indian Reservations in the USA.' 
maniacs who built those first bombs sited themselves with no sense of irony whatsoever in an area surrounded by lands stolen from Native people, and tested them at a future American mecca they named "Trinity" (ref. John Donne, or Christianity, for more on that one) near the Mescalero Apache reservation, situated in an area known as the Jornada del Muerto, or "Day's Journey of the Dead," named for the time it took, as well as one's potential fate in crossing "sixty miles of desert, very little water, and numerous hostile Apaches."13

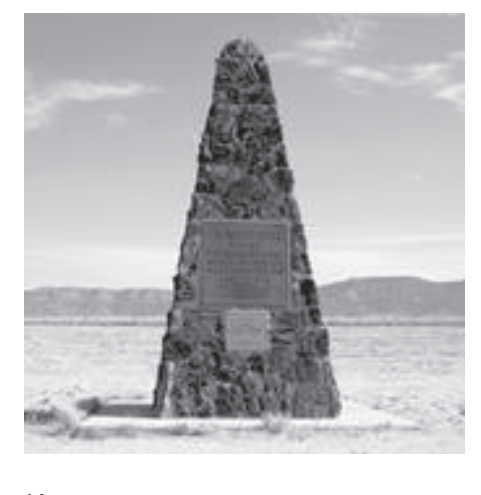

14

This then is the exposed sinew of the American/Canadian/ Australian/ New Zealand/South African settler story, the taut thread that runs throughout settler stories across the globe-the dread, the unease, and the ultimate realization that the invader holds no true connection to place, to the colonized space. How better to overcompensate than to situate engines of destruction in those most uncanny, unheimlich, unknown spaces. And while Broadbent tells us that Otto proclaimed "ungeheuer (used interchangeably with unheimlich) is the closest German rendering of the Greek word deimos," we would do well when thinking of settlers to consider the literal translation of unheimlich"unhomely," or "homeless" (106). The stories we'll examine show the folly of settler worldscape transformation, of avoiding the truth of the first people's relationship to the land. As the child conquers his or her fear of the dark, so does the settler stare into the abyss of the stolen landscape and contemplates it's refashioning, it's renaming, repurposing, and remeaning. Occasionally, though, that void returns the gaze. These are some of the tales Jones tells.

13 G. Walker. n.p. 'Trinity Atomic Web Site.' <https://www.abomb1.org>. (Accessed April 30, 2015.) 14 Atomic Age Mecca-'Trinity Site Obelisk National Historic Landmark' by Samat Jain - Flickr: Trinity Site Obelisk National Historic Landmark. Licensed under Public Domain via Wikimedia Commons - http://commons.wikimedia.org/wiki/File:Trinity_Site_Obelisk_National_Historic_ Landmark.jpg 


\section{Coming Home}

Moving from Sterling City's (and though not examined here, Jones's 2010 It Came from Del Rio makes a nice pairing with Sterling City in what could be the start of a "Better Evolution Through Radiation" series) firestorm introduction we catch up with one of the main characters, cotton-farming Lee. He's upset because caterpillars have overrun his fields and property. It's crucial to note though, that it's not the presence of the caterpillars, rather it's their inactivity, in his human eyes, that he finds problematic:

Lately, you couldn't even drive on blacktop anymore without crunching caterpillars. It was a game to Lee. Not because they messed with the cotton much - they didn't-but because they didn't eat boll weevils, like he thought they should. (Kindle Locations 100-102)

He reminisces about learning the proper form for stepping on those caterpillars back in school and shooting their guts on his female classmates, but then is stopped short when he goes to check on his farmhand, Doby. "It had made him smile, then. He wasn't smiling now" (Kindle Location 105). The two-foot long specimen of the red and black bristly-haired caterpillar

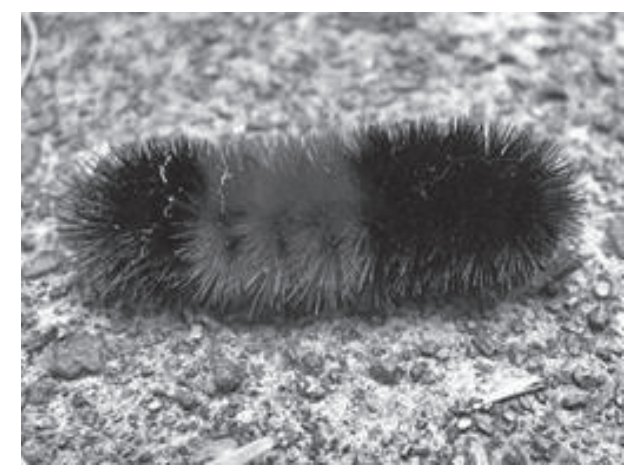

15

he encounters has Doby petrified and near tears. "Lee took an involuntary step back. The caterpillar seemed to watch him take it. It made him feel weak in the bowels, made him wish he were standing on the hood of the tractor too" (Kindle Locations 111-113). And if the caterpillar is uncanny, a traveler from the void, from space, from the abyss, then Lee may in fact be staring into the face of God, ruler of the void, who here stares back, and watches. This sentience, this canny being seems to be... unhappy. Perhaps it knows of the farmer's previous transgressions, and though the farmer's estranged wife "liked how those shiny

15 Like this little guy, but huge. "Salad Science," n.p. 
leaves would be tilted over just the same, facing the same direction, waiting for day-confident that it was coming" (Kindle Location 1060),

The one thing Lee had never thought to use against her, even towards the end, when things were going from bad to worse, was that that sheen on the leaves in the morning was the oily residue of pesticide. That, when he drove into the field, he had to go slow to keep from running over all the poisoned burrow owls that were dying anyway' (Kindle Locations 10611063).

Lee seems... unfazed, if slightly confused. He continues to talk to Doby, telling the young farmhand that his wife Zoe has left him yet again, seemingly for the final time: "'She walked'," Lee said, cutting him short. What he was getting at was that maybe this was her-his butterfly of a wife, going backwards, to her natural state-or maybe this had eaten her' (Kindle Locations 117-119). While Lee contemplates who or what he might be looking at, Doby has some thoughts of his own. Later, when conversation returns to the caterpillar (which has been growing and molting right along), Lee's been thinking about probability and statistics: "Get enough caterpillars going one season, there's bound to be a freak giant or two. Just numbers. And luck" (Kindle Locations 282-283). Doby offers his thoughts on Phobos: "'When it blew up or whatever,' Doby said, his voice flat enough that it was like he was reciting, 'there were like [...] x-rays, or gamma rays, or something'"' (Kindle Locations 290-291). Readers of The Incredible Hulk ${ }^{\circledR}$ know what that can mean. Doby hedges his bet, though. Adding to the warping, destructive powers of radiation, he throws in this bit of information to help make his argument: "'It snowed in one of those bible cities,' he said" (Kindle Location 294). Lee responds like most "grown-ups": "You been watching too much television, kid" (Kindle Location 295). While television can represent a void in its own right, here we recognize what Jones is doing-deftly showing us the interiority of not fear, but dread, of how each generation thinks it's the last, how apocalypse has been reserved for them, and how, when we root against the prob and stats characters, the voices of reason, we evince our desire for something big to happen in our lifetimes, if not for questionable reasons, perhaps at least for the sheer if guilty relief it might bring.

That deft use of the subtle character sketch continues when Jones has Lee take a different tack as he backs up his sentiments about television being a waste-he appears to be a fan of another medium to get his news - while giving us some insight as to his sense of self:

The show on the radio last night had been another idea about the leaky moon over Mars: because its orbit or whatever had been decaying, spi- 
raling the moon in to the planet over thousands of years, some people were saying that that was design, that the moon had been inseminated with carbon and amino acids and RNA, so that when the moon crashed down to the surface, long after humans were gone, things could get started all over again (Kindle Locations 480-483).

As a farmer, Lee would be more apt to see the hand of a cosmic planner, a possibly even benevolent cultivator in charge of an orderly universe (while also unable to see that hand in the body of a caterpillar, a farmer's nuisance, giantsized or not). Jones, though, isn't going to let the reader off that easily:

Another theory about the moon was that it was Hell, like from the Bible. That all that blackness that had spewed out from it was the largest prison break the solar system had ever seen. That now humanity was going to get what it deserved, for messing with things it should have left alone. (Kindle Locations 487-489)

\section{Home Base}

Things better left alone are not mentioned by name but seem to be at and to begin the heart of Chapter Six, Jones's shorter offering on a future zombie apocalypse (see his excellent 2014 The Gospel of $Z$ for a novel-length treatment). No cause is given for the mass of interstate shufflers, but the reader, likely well-versed in the various causes of zombie outbreaks/plagues/disasters is left to fill in her own blanks. To give you a sense of the setting (and why the outbreak in this area seems so... well-deserved), I'll turn to a story note Jones provided:

I set the story there b/c of that trip I took to Dartmouth and Yale. I drove over to see a friend, Paul Tremblay. we ate, then he said get back on [...] I think it was 95 and that'll take me wherever I was going. so I did. but I guess I went the wrong way. called him 30-40 minutes later, trying to explain what I was and wasn't seeing, and he set me right. so, for me that stretch of road is like magic or wrong or a black hole. seemed a good place for zombies. but, that bipedalism stuff, that's what I like to read about more than any other single thing. this story's just like a casing for me to talk about it some. ${ }^{16}$ 
Ah, zombies in the Ivy League? Perfect. Even better, Jones gives us an immediate sense of a world gone, well, gone:

They were eighty miles from campus, if miles still mattered.

It had been Dr. Ormon's idea.

Dr. Ormon was Crain's dissertation director. If dissertations still mattered.

They probably didn't.

Zombies. Zombies were the main thing that mattered these days (Kindle Location 13).

For the record, Crain's thesis, dealing with the emergence of bipedalism in humans, "was that a lack of body hair, due to the forest's retreat, meant that the mothers were having to carry their infants now, instead of letting them hang on. They had no choice but to stand up" (Kindle Locations 51-52). As professor and grad student continue that dance from the old world, the dance of suggest, and write, and revise, they each begin to (re)structure this new world, as Crain contemplates 'a map of Paleo-America tacked on the wall' (Kindle Locations 43-44).

Crain appears to have a jump on his professor, as "Paleo-America" is quickly beginning to look a lot like "Paleo-Earth." The relentless horde/herd of posthumanity is swiftly changing the rules of the game as well as the landscape of this Anthropogenic world. Though they're doing the things our first zombie pictured is famous for ("Coming to get you, Barbara"), they probably look more like the guy in the second pic hanging out with Bela Lugosi, bringing us full circle back to this century's first Hollywood depictions of zombies:

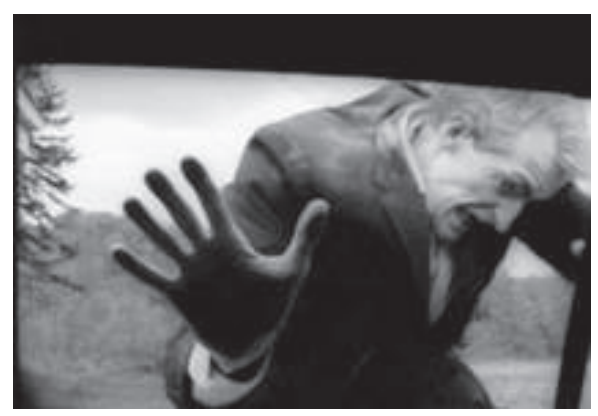

17

17 Screen shot, Night of the Living Dead (1968) 


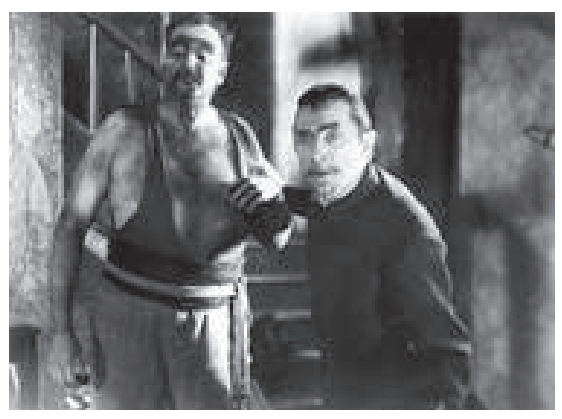

18

The grad student contemplates their "postapocalyptic" condition: "Crain tried to frame their situation as a return to more primitive times." And what does his analytic training tell him? "What the plague was doing, it was resetting humanity. Hunting and gathering were the order of the day, now, not books or degrees on the wall" (Kindle Locations 35-36). The professor expresses a differing opinion, aloud: "'It does still matter,' he said. 'All our - this. Our work, our studies, the graduate degrees. It's been a manual, a guide, don't you see?'” (Kindle Locations 42-43). As they argue over footnotes in Crain's dissertation, the grad student cuts to the chase: "Now that it was the postapocalypse, they could call things what they were" (Kindle Locations 46-47). While the pair follow the horde/herd across this new worldscape, in search of food, of "available sources of protein" (Kindle Locations 47-48), the still-focused grad student has an additional goal in mind, his training serving him well. In all of their postapocalyptic roaming and meandering, they battle as in the halls of grad school, but ultimately humanity (such as it is, and the ending definitely showcases its two possible tracks) and its innate curiosity is found in that line: "This is how you prove a thesis" (Kindle Locations 87-88).

We eventually discover that Crain's esteemed dissertation director turns out to be not as... human as we'd like, and if he represents us, well, posthumanity is in trouble. With no spoilers, l'll say that Jones's grad student makes a redemptive choice. And ever dedicated to his project, he leaves "Behind him, the all-too-human horde, exhausting the landscape. This was his thesis in action. His final proof" (Kindle Locations 228-229).

\section{Home?}

Intrepid astrophysics grad student Billy Hanson, working in the post-doc world of academe, comes up with a research proposal (known to his director as the "Spatial Tunneling Debacle" [Jones, Van Alst, 365]); his vision tells him: "The headlines would be along the lines of 'Mankind Looks for God,' and have Billy's 
picture under it somewhere, smiling just mischievously enough to usher in another age, where the scientists could again be celebrities" (Jones, Van Alst, 365).

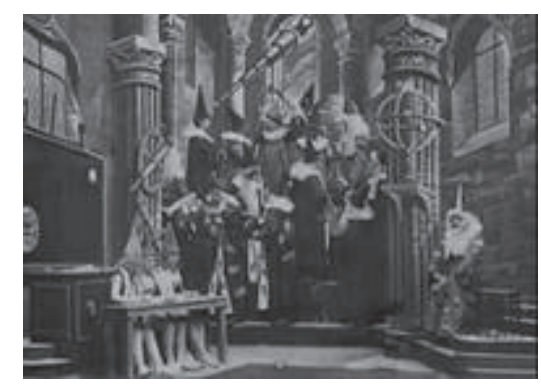

19

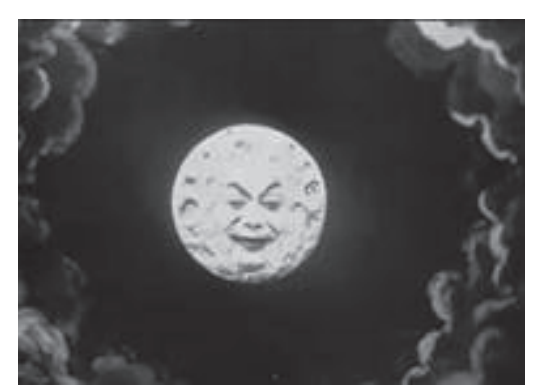

20

\section{Probably not this kind of telescope, but...}

No. Not God.

Billy, looking back on events that do indeed usher in another age, attempts to rationalize or at least deflect the blame that only he can be responsible for. Jones indicts our Stimpy-esque inability to refrain from pushing red buttons:

Or, if there was any fault, it was that he was human in the first place, a species built specifically, it would seem, to push buttons clearly marked DON'T PUSH, a species that had only evolved in the first place because it kept reaching up to that next level of the beach instead of being satisfied with where it already was. (Jones, Van Alst, 363)

As Billy climbs that beach looking for God on our behalf, Broadbent tells us via Otto that "the choral ode of Sophocles' Antigone [...] demonstrates how deimos is used to speak of the uniqueness of human nature (though for Billy Hanson [and the rest of us] that 'uniqueness' is about to become utterly point-

19 Screen shot, Le Voyage dans La Lune (1902)

20 lbid. 
less)" and that while "there is much in the world that is uncanny [...] nothing is more uncanny than the being of man (unless you have a deep space telescope, LOL, right, Billy?)" (Broadbent, 106).

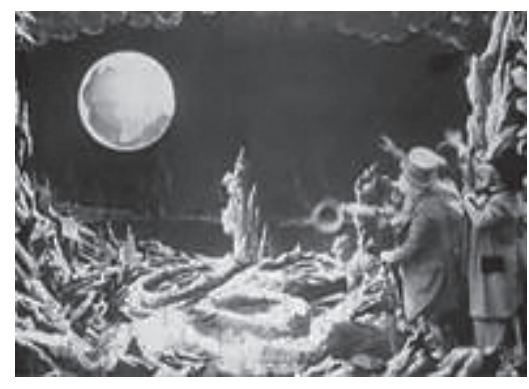

21

\section{But still, sometimes, someone looks back.}

In the end, this uncanny, unheimlich is ourselves (or, depending on positionality, the settlers) alienated from our/themselves, Western humanity's uncomfortable relationship with its mother, Earth. In Broadbent's work on Chauvet, Heidegger, and Benedict XVI, he considers Heidegger's ruminations on the individual in the presence of God, describing an "impenetrable mood of anxious dread," and also references Kierkegaard to more fully describe that "dangerous moment" (Broadbent, 114). For young Billy Hanson, for Doby and Stace, for Crain (and Eve, maybe), for us, we consider the full passage from Kierkegaard, along with his question:

What fair weather is for the sailor, going on living at the same pace with others and with the generation is for the individual person, but the decision, the dangerous moment of collecting himself when he is to withdraw from the surroundings and become alone before God and become a sinner-this is a stillness that changes the ordinary as the storm does. He knows it all, knows what is to happen to him, but he did not know the anxiety that grips him when he feels himself abandoned by the multiplicity in which he had his soul; he did not know how the heart pounds when the help of others and the guidance of others vanish in stillness; he did not know the shuddering when it is too late to call for human help, when no one can hear him-in short he had no conception of how the knower is changed when he is to appropriate knowledge.

Is it perhaps also the case with you, my listener? ${ }^{22}$

$21 \mathrm{lbid}$.

22 Kierkegaard, 36-37 
It would seem that the best move to end this piece would read: "Beware that, when fighting monsters, you yourself do not become a monster [...] for when you gaze long into the abyss, the abyss gazes also into you" (Friedrich Nietzsche). But I think maybe Jones found us something during all his abyss staring. Sterling City concludes thusly:

The news reports that night all said that the world, it was ending.

They were wrong.

It was beginning again. (Kindle Location 1259)

\section{Works Cited:}

Broadbent, Hal St John. Heidegger - Chauvet - Benedict XVI: The Call of the Holy. London: T \& T Clark, 2012.

Frantz, Klaus. 'The Role of Mining on Indian Reservations in the USA.' CG Cadernos De Geografia 17, no. 1998, 259-65. Accessed July 21, 2018. http:// www.uc.pt/fluc/depgeo/Cadernos_Geografia/Numeros_publicados/ CadGeo17/artigo39.

Jones, Stephen Graham. The Bird Is Gone: A Manifesto. Normal, III.: FC2, 2003. Jones, Stephen Graham. Sterling City. Kindle ed. Nightscape Press, 2013.

Jones, Stephen Graham. Chapter Six. Kindle ed. Tor Books, 2014.

Jones, Stephen Graham, and Theodore C. Van Alst. The Faster Redder Road: The

Best UnAmerican Stories of Stephen Graham Jones. Albuquerque, New Mexico: University of New Mexico Press, 2015.

Kierkegaard, S., and Howard V. Hong. Three Discourses on Imagined Occasions. Princeton, N.J.: Princeton University Press, 1993.

Le Voyage Dans La Lune. Dir. Georges Méliès. France: Star Film, 1902. Film. Public Domain

Night of the Living Dead. Dir. George Romero. Perf. Duane Jones, Judith O'Dea. Continental Distributing, 1968. Film. Public Domain

'Planetary Images.' Solar System Exploration. June 22, 2011. Accessed April 22, 2018.

'Planetary Names: Crater, Craters: Swift on Deimos.' Gazetteer of Planetary Nomenclature. July 22, 2008. Accessed April 22, 2018.

'Planetary Names: Crater, Craters: Voltaire on Deimos.' Gazetteer of Planetary Nomenclature. July 22, 2008. Accessed April 22, 2018.

'Salad Science: Coaxing Caterpillars to Reveal the Secrets of Their Leafy Desires.' Smithsonian Science News. September 15, 2009. Accessed July 28, 2018.

Walker, Gregory. 'Trinity Atomic Web Site.' Trinity Atomic Web Site. (Accessed April 30, 2018.)

White Zombie. Dir. Victor Halperin. Perf. Bela Lugosi. United Artists, 1932. Film. Public Domain 


\section{GELEGENTLICH IST ER EIN SOMNIIZIDALES MANIAC: WELTLANDSCHAFTEN VON STEPHEN GRAHAM JONES}

Umweltaktivismus und Bewahrung des Landes, Anerkennung unserer gemeinsamen Verantwortung gegenüber dem Planeten, der Unci Maka, der Mutter Erde, unserer Heimat; Das sind Liebespflichten, die wir als Menschen mit hingebungsvoller Regelmäßigkeit annehmen. Aber was passiert, wenn wir uns Geschichten anschauen, die die Welt vollständig zerstören könnten, unsere Geschichten und Häuser neu gestalten, umformen, zurückfordern und neu gestalten (oder in einer restaurativen Bewegung sogar umbenennen könnten)? Was ist die Rezeption für Werke, die die Erwartungen der Hingabe an die Umwelt in der amerikanischen Ureinwohnerliteratur trotzen? Diese Adresse historische Auslöschung durch die Umgestaltung der Zukunft?

In diesem Artikel werden einige von Stephen Graham Jones, produktiven Werken untersucht, darunter Sterling City, „Wie Billy Hanson die Erde zerstörte und alle anderen" sowie Kapitel 6, die auf verschiedenen Plattformen und Sammlungen veröffentlicht wurden. In jedem Fall werden die beschriebenen Welten als Heimat- und Zukunftsgeschichte entschlossen zurückgefordert, vielleicht aus guten Gründen und vielleicht aus nicht so guten Gründen. Die Welten, aus denen Sie wählen können, sind jedoch diejenigen, die Ihnen Alpträume oder zumindest eine Pause bereiten werden, selbst bei Tageslicht.

Stichwörter: Indianer, Stephen Graham Jones, Blackfeet, Fiktion, Science-Fiction, Apokalypse und Post Apokalypse, Zombies, Siedler, Amerika. 